\title{
PEMANFAATAN UBTECH HUMANOID ROBOT SEBAGAI MEDIA PEMBELAJARAN KEPADA GURU MENUJU ERA REVOLUSI INDUSTRI 4.0 DIBIDANG PENDIDIKAN UNTUK ANAK AUTIS DI SEKOLAH PEKANBARU LAB SCHOOL
}

\author{
Anip Febtriko' ${ }^{1}$, Wita Yulianti' ${ }^{1)}$, Tri Rahayuningsih ${ }^{2)}$ \\ 1)Program Studi Teknik Informatika, Fakultas Teknik, Universitas Abdurrab \\ 2)Program Studi Psikologi, Fakultas Psikologi, Universitas Abdurrab \\ Jl. Riau Ujung No 73 Pekanbaru \\ Email: anipfebtriko@gmail.com
}

\begin{abstract}
ABSTRAK
Proses pembelajaran merupakan bagian yang penting dari dunia pendidikan terutama pendidikan untuk anak autis, karena melalui pembelajaran guru bisa berinteraksi dan mengevaluasi peserta didiknya secara langsung. Permasalahan yang muncul adalah bagaimana cara memberikan pembelajaran yang baik kepada anak autis yang memiliki hambatan dan kendala selama ini. Sekolah Pekanbaru Lab School merupakan tempat untuk anak autis dengan jumlah 30 orang dengan rentang usia 6 - 15 tahun, dimana sekolah Pekanbaru Lab School juga menghadapi permasalahan terhadap pemberian pengajaran atau pembelajaran kepada anak auits. Ada lima permasalahan yang ditemukan dalam pembelajaran di Sekolah Pekanbaru Lab School untuk menghadapai era Revolusi Indusitri 4.0 dibidang pendidikan sehingga menjadi hambatan yaitu Metode pembelajaran, Peran guru dalam pembelajaran, Peserta didik, Sarana dan Prasarana, Peran Orang tua. Dengan permasalahan yang dihadapi oleh sekolah Pekanbaru Lab School sebagai mitra Program Kemitraan Masyarakat perlu solusi untuk mengatasi permasalahan tersebut dan mempersiapkan sekolah Pekanbaru Lab School menuju era Revolusi Industri 4.0 dibidang Pendidikan. Pertama pemilihan metode pembelajaran yang baik sehingga meningkatkan ketrampilan mengajar guru dengan cara memperbarui Kurikulum yang berintegrasi dengan teknologi terutama teknologi Robot. Kedua adalah meningkatkan peran guru dalam pembelajaran secara aktif untuk membimbing anak autis dengan cara melanjutkan pendidikan guru ke pendidikan yang lebih tinggi dan memfasiltasi guru dalam kegiatan pelatihan tentang anak autis. Ketiga peserta didik yang meningkat jumlahnya dan memmpunyai karakter yang berbeda maka solusinya adalah dengan cara penambahan guru sebagai pendidik dans sesuia dengan kompentensi dn keahlian masing-masing guru terhadap tipe atau karakter anak penyandang autis. Keempat sarana dan prasarana adalah dengan menambahkan fasilitas seperti penambahan ruagan kelas dan ruangan terbuka serta menambahkan media terapi dengan memberikan unsur teknologi seperti teknologi Ubtech Humanoid Robot. Kelima peran orang tua adalah dengan cara orang tua harus berperan aktif dalam pebelajaran anak autis yang dilakukan di rumah dan orang tua tentu akan diberikan pelatihan atau forum diskusi untuk memahami anak mereka lebih mendalam.
\end{abstract}

Kata Kunci : Revolusi Industri 4.0, Autis, Pembelajaran, Ubtech Humanoid 


\section{ABSTRACT}

The learning process is an important part of the world of education, especially education for autistic children, because through learning teachers can interact and evaluate their students directly. The problem that arises is how to provide good learning to autistic children who have obstacles and obstacles so far. Pekanbaru Lab School is a place for autistic children with 30 people in the age range of 6-15 years, where Pekanbaru Lab School also faces problems with the provision of teaching or learning to auits. There are five problems found in learning at the Pekanbaru Lab School to face the Indonesian Revolutionary era 4.0 in the field of education so that it becomes an obstacle namely the learning method, the role of the teacher in learning, students, facilities and infrastructure, the role of parents. With the problems faced by Pekanbaru Lab School as partners of the Community Partnership Program, a solution is needed to overcome these problems and prepare the Pekanbaru Lab School towards the era of the 4.0 Industrial Revolution in the field of Education. The first is the selection of a good learning method so as to improve teacher teaching skills by updating the curriculum that integrates with technology, especially Robot technology. Second is to increase the role of teachers in active learning to guide autistic children by continuing teacher education to higher education and facilitating teachers in training activities on autistic children. The three students who increase in number and have different characters, the solution is to add teachers as educators and according to competence and expertise of each teacher on the type or character of children with autism. The four facilities and infrastructure are by adding facilities such as adding classrooms and open spaces and adding therapeutic media by providing technological elements such as Ubtech Humanoid Robot technology. The fifth role of parents is by the way parents must play an active role in the learning of autistic children at home and parents will certainly be given training or discussion forums to understand their children more deeply.

Key words: Revolusi Industri 4.0, Autis, Learning, Ubtech Humanoid 


\section{PENDAHULUAN}

\section{ANASLISA SITUASI}

\section{Sekolah Pekanbaru Lab School}

Sekolah Pekanbaru Lab School beralamat di jalan Taman Sari Nomor 30 Kelurahan Tengkerang Selatan Kecamatan Bukit Raya di Kota Pekanbaru Provinsi Riau. Pekanbaru Lab school telah berdiri sejak tahun 2010 dan mempunyai visi adalah MEMPERSIAPKAN ANAK UNTUK HIDUP LEBIH MANDIRI. Berdiri atas dasar keprihatinan terhadap banyaknya kebutuhan pelayanan di bidang terapi dan edukasi bagi anak-anak dengan kebutuhan khusus.

\section{Peserta Didik}

Peserta Didik atau anak autis yang ada di sekolah Pekanbaru Lab School dengan jumlah 30 orang anak penyandang autis dengan bermacam gejala yang dialami oleh anak autis tersebut.

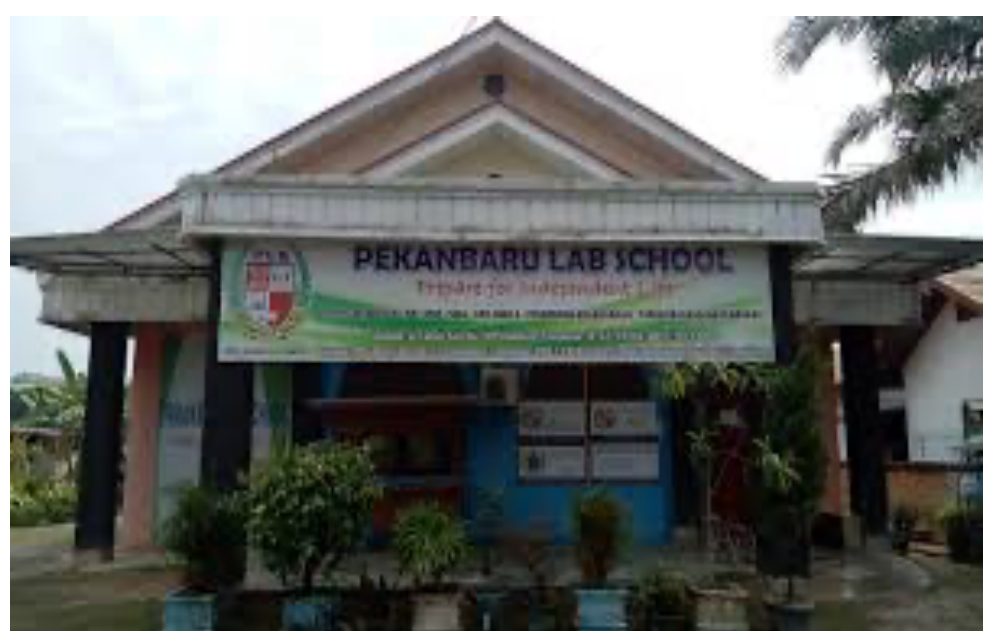

Gambar 1. Sekolah Pekanbaru Lab School

\section{Tenaga Kependidikan atau Guru}

Jumlah guru yang ada di sekolah Pekanbaru Lab School sebagai tenaga pendidik sebanyak delapan orang dengan latar belakang pendidikan yang berbeda dan ada sebagian dari guru di sekolah Pekanbaru Lab School yang masih dalam proses perkuliahan.

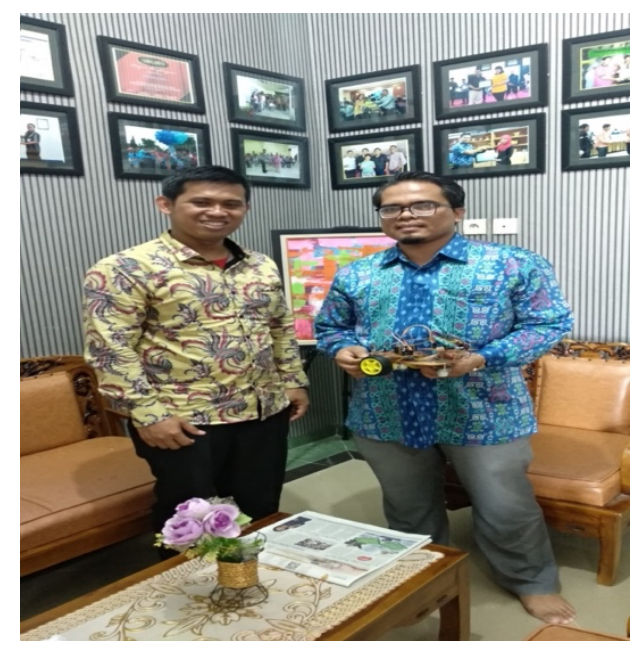


Gambar 2. Ketua Tim Pengabdian bersama Kepala Sekolah Pekanbaru Lab School

\section{Sarana dan Prasarna}

Sekolah Pekanbaru Lab School memiliki dan menyediakan fasilitas yang masih kurang yaitu sepuluh ruangan yang terdiri dari ruang pimpinan, ruang tamu, ruang guru, ruangan ibadah dan ruangan kelas. Rata-rata ukuran dari $3 \mathrm{~m}$ x $3 \mathrm{~m}$. Sementara untuk ruang terbuka masih terbatas dengan ukuran $4 \mathrm{~m}$ x $5 \mathrm{~m}$ sehingga untuk kegiatan bermain untuk anak autis masih kurang. Sarana dan prasarana di bagian media terapinya masih menggunakan media terapi yang lama dan belum menggunakan unsur teknologi. Gambar berikut menjelaskan kondisi dan fasilitas yang dimiliki oleh sekolah Pekanbaru lab School

\section{Metode pembelajaran}

Jadwal kegiatan layanan pendidikan di sekolah Pekanbaru Lab School dari senin-jumat dan dimulai jam 08:00 - 16:00 WIB. Tetapi metode pembelajaran masih bersifat dasar seperti dapat dilihat pada gambar di bawah ini yang belum menggunakan unsur teknolgi, tepatnya belum menggunakan unsur robotik sebagai media terapi. Disamping media terapi, Pekanbaru Lab School masih meggunakan kurikulum yang lama dan belum memasukan unsur teknologi didalam kurikulum dan Evalusi yang dilakukan masih belum dilakukan secara maksimal.

\section{TINJAUAN PUSTAKA}

\section{Pengertian Metode Pembelajaran}

Metode merupakan salah satu strategi atau cara yang digunakan oleh guru dalam proses pembelajaranyang hendak dicapai, semakin tepat metode yang digunakan oleh seorang guru maka pembelajaran akan semakin baik.Metode berasal dari kata methodos dalam bahasa Yunani yang berarti cara atau jalan. (Olvkhg, Uhvsrqvl, \& Rgxfwlrq, 2012) berpendapat bahwa metode merupakan perencanaan secara menyeluruh untuk menyajikan materi pembelajaran bahasa secara teratur, tidak ada satu bagian yang bertentangan, dan semuanya berdasarkan pada suatu pendekatan tertentu. Pendekatan bersifat aksiomatis yaitu pendekatan yang sudah jelas kebenarannya, sedangkan metode bersifat prosedural yaitu pendekatan dengan menerapkan langkah-langkah.

\section{Terapi Autis}

Penyandang autis sebaiknya berdiet gluten dan kasein yang dikenal diet GF/CF (gluten free casein free). Selain diyakini dapat memperbaiki gangguan pencernaan, juga bisa mengurangi gejala atau tingkah laku autistik anak. Diet GF/CF sebenarnya merupakan terapi penunjang yang tidak dapat bersifat langsung menyembuhkan autisme, namun diharapkan dapat mempercepat proses penyembuhan (Martins, Bonito, Andrade, Albuquerque, \& Chaves, 2015).

\section{Pengertian Robot}

Pemahaman manusia satu dengan yang lain mengenai robot berbeda-beda. (Schwaibold, Wiesend, \& Bach, 2018) menurut kamus Webster, robot adalah sebuah alat otomatis yang dapat melakukan fungsi tertentu berdasarkan kebutuhan manusia. Sedangkan menurut kamus Oxford, robot merupakan mesin yang diprogram oleh komputer, sehingga dapat melakukan serangkaian tugas rumit secara otomatis. 


\section{METODE PELAKSANAAN}

\section{Prosedur Kerja}

Metode pelaksanaan kegiatan dalam pelaksanaan Pemanfaatan Ubtech Humanoid Robot sebagai media pembelajaran kepada guru menuju era Revolusi Industri 4.0 dibidang pendidikan untuk anak autis di sekolah Pekanbaru Lab School prosedur kerja dapat dilihat di gambar.

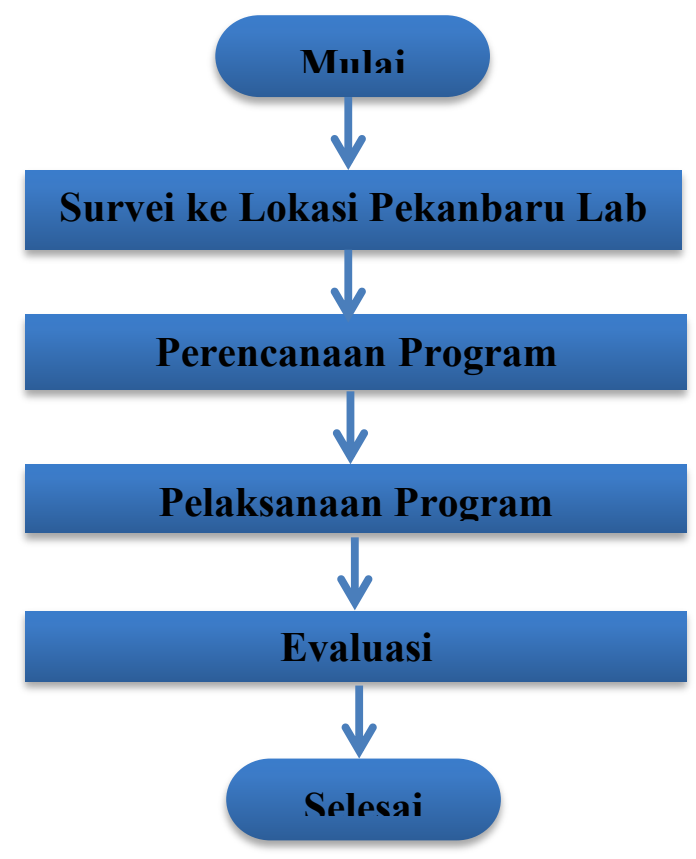

Gambar 3. Prosedur Kerja

\section{Survei ke Lokasi Pekanbaru Lab School}

Dalam tahap survei ini adalah tahap untuk pengumpulan data awal yang diperlukaan untuk kegiatan Program Kemitraan Masyarakat di sekolah Pekanbaru Lab School. Untuk mendapatkan data yang diperlukan, maka digunakan teknik sebagai berikut :

\section{Wawancara}

Dalam pengabdian ini akan dilakukan wawancara kepada pihak Mitra baik itu kepada kepala sekolah Pekanbaru Lab School, guru, karyawan dan anak autis untuk mendapatkan beberapa yang diperlukan dalam pengabdian ini. Wawancara ini dilakukan dengan teknik wawancara yang digunakan adalah sebagai berikut :

1. Wawancara terstruktur

2. Wawancara tidak terstruktur dan

3. Wawancara mendalam

\section{Observasi}


Pada ahap observasi ini adalah bagaimana mengamati secara langsung kegiatankegiatan yang berlangsung di sekolah Pekanbaru Lab School. Pengamatan ini tentu membutuhkan waku yang lama, karena mengamati dari awal kegiatan sampai akhir kegiatan. ini dilakukan supaya mendapatkan data yang lebih objektif dan sesuai dengan kenyataan dilapangan. Media yang dilakukan untuk melakukan observasi ini adalah sebagai berikut :

1. Buku dan Pulpen, sebagai alat untuk mencatat hasil pengamatan

2. Kamera, digunakan untuk mengambil gambar sebagi dokumentasi dari hasil pengamatan

\section{Perencanaan Program}

Setelah melakukan survei di sekolah Pekanbaru Lab School maka perlu dilakukan perencanaan program. Dari hasil survei ada data dan informasi yang dapat diolah sebagai pembuatan perencanaan program. Berikut ini adalah perencanaan program yang akan dilakukan dan dapat dijelaskan sebagai berikut :

1. Mempersiapkan buku panduan tentang cara pemakaian Ubtech Humanoid Robot. Buku ini akan menjelaskan cara pemakain secara jelas dan lengkap sehingga memudahkan pihak ang menggunkan terutama guru sebagai pihak yang memberikan pembelajaran kepada anak autis dan Buku ini juga akan diperbanyak sesuai dengan kebutuhan guru.

2. Memepersiapkan Ubtech Humanoid Robot sebagai media untuk dijelaska kepada guru pada waktu Pemanfaatan.

3. Mempersiapkan materi tentang Pemanfaatan Ubtech Humanoid Robot kepada guru.

\section{Pelaksanaan Program}

Setelah disusun rencana program yang telah disampaikan pada penjelasan diatas maka tindakan berikutnya adalah tahap pelaksanaan program yang akan dilakukan di sekolah Pekanbaru Lab School. Berikut ini adalah bentuk pelaksanaan program yang dilakukan dan dapat dijelaskan sebagai berikut :

1. Melakukan Workshop dengan tema Pemanfaatan Menggunakan Ubtech Humanoid Robot Sebagai Media Pembelajaran Kepada Guru Menuju Era Revolusi Industri 4.0 Dibidang Pendidikan Untuk Anak Autis Di Sekolah Pekanbaru Lab School.

2. Melakukan Forum Grup Diskusi (FGD) dengan pihak sekolah yaitu dengan Kepala sekolah Pekanbaru Lab School.

3. Melakukan FGD dengan guru sebagai pembimbing anak autis dalam melaksanakan pembelajaran.

4. Melakukan pertemuan dengan anak penyandang autis, dengan agenda melakukan pembinaan dan memberikan motivasi.

\section{Evaluasi}

Evaluasi ini merupakan tahapan terakhir dari seluru rangkaian kegiatan dalam Program Kemitraan Masyarakat di sekolah Pekanbaru Lab School. Evaluasi yang dilakuan pada tahap akhir ini adalah dengan cara membuat alat ukur yang digunakan untuk guru dan orang tua . Alat ukur yang digunakan dapat dijelaskan sebagai berikut :

1. Alat Ukur Evaluasi (Skala Kemandirian Anak Autis) untuk Orang Tua 
2. Alat Ukur Evaluasi (Skala Efektifitas Metode Pembelajaran Pada Guru)

3. Alat Ukur Evaluasi (Skala Penerimaan Teknologi Robot).

\section{Partisipasi Mitra}

Dalam pelaksanaan Pegabdian Masyarakat ini di sekolah Pekanbaru Lab School, Partisipasi Mitra dapat dilihat dari :

1. Partisipasi Mitra pada saat melakukan wawancara dan observasi, dimana Mitra berpartisipasi dalam pemberian data secara lengkap yagn dibutuhkan dalam pengabdian ini.

2. Partisipasi Mitra pada saat melakukan penyusunan dalam perencanaan program, dimana Mitra berpatisipasi melakukan sumbangsi ide dalam penyusunan program untuk dilakukan pada kegiatan workshop.

3. Partisipasi Mitra pada saat pelaksanaan program, Mitra sumbangsih dalam pengisian acara dalam kegiatan Workshop.

4. Mitra berpatrisipasi dalam menindak lanjuti progam yang telah diberikan dengan cara melaksanakan hasil worksop atau pelatihan yang diberikan untuk diterapkan dalam proses pembelajaran kepada anak auits.

\section{HASIL DAN PEMBAHASAN}

\section{Hasil Pembahasan}

Dengan adanya Pemanfaatan menggunakan Ubtech Humanoid Robot sebagai media pembelajaran kepada Guru menuju era Revolusi Industri 4.0 dibidang pendidikan untuk anak autis di sekolah Pekanbaru Lab School.

\section{Solusi Dan Luaran Untuk Aspek Peserta Didik}

Ada dua permasalahan yang ada pada aspek peserta didik yaitu peningkatan jumlah autis dan tipe anak yang berbeda-beda, maka untuk mengatasi permasalahan tersebut adalah dengan cara sebagai berikut :

1. Peningkatan jumlah autis

a. Solusi Peningkatan jumlah autis

b. Jenis luaran yang dihasilkan

2. Tipe anak yang berbeda-beda

a. Solusi tipe anak yang berbeda-beda

perlu adanya Pemanfaatan kepada guru agar bisa lebih memahami tentang penanganan prilaku anak autis yang beragam-ragam. Dengan tipe yang beragam ini tentu menimbulkan kesulitan untuk mengatasi anak tersebut.

b. Jenis luaran yang dihasilkan

Dengan solusi yang di atas maka mitra harus tentu mengambil kebijakan tentang memberikan pelatihan kepada guru dengan cara mengikuti agenda pelatihan atau workshop, salah satunya adalah dengan mengikuti Pemanfaatan menggunakan Ubtech Humanoid Robot.

\section{Solusi dan Luaran Untuk Aspek Peran Orang Tua}

1. Solusi aspek peran orang tua

2. Jenis lauaran yang dihasilkan

\section{Solusi dan Luaran Pada Aspek Guru}


Permasalahan-permasalahan yang ditemukan berikutnya adalah pada aspek guru adalah jumlah guru yang kurang, latar belakang pendidikan dan kurangnya pelatihan. dengan permasalahan di atas maka dapat diberikan solusi yang dijelaskan sau persatu sebagai berikut :

1. Jumlah guru yang kurang

a. Solusi jumlah guru yang kurang

b. Jenis luaran yang dihasilkan

2. Latar belakang pendidikan

a. Solusi dari latar belakang pendidikan

Dengan latar belakang pendidikan yang berbeda dan sebagian dari guru belum berpendidikan strata 1

b. Jenis luaran yang dihasilkan

Setelah melakukan Pemanfaatan menggunakan Ubtech Humanoid Robot guru akan melakukan untuk melanjutkan perkuliahan yang lebih tinggi.

3. Kurang pelatihan

a. Solusi dari kurangnya pelatihan

Pelatihan merupakan solusi untuk mengatasi masalah guru dalam pembelajaran.

b. Jenis luaran yang dihasilkan

Dengan melihat penjelasan solusi di atas maka perlu jenis luaran yang dihasilkan yakni mitra atau sekolah Pekanbaru Lab School.

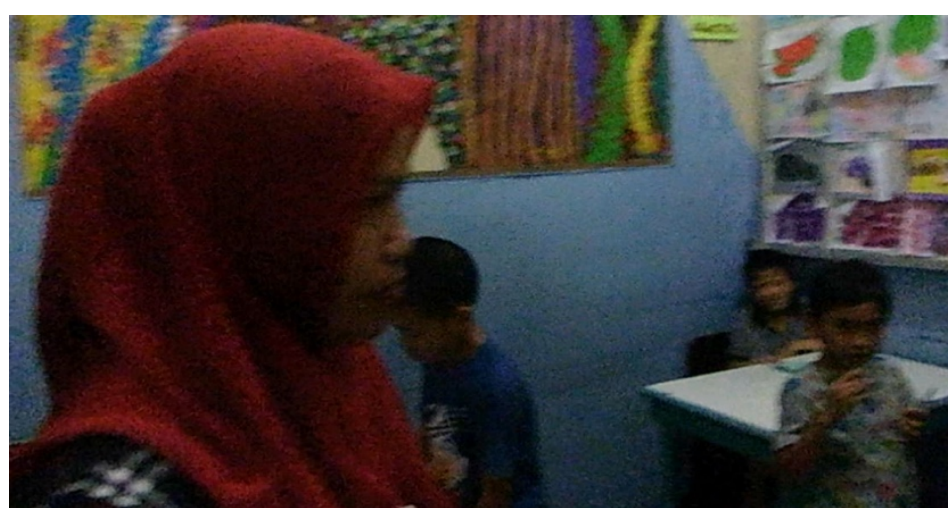

Gambar 4. Pendampingan yang dilakukan oleh guru pembinbing

\section{Solusi dan Luaran Sarana dan Prasarana}

Permasalahan yang ditemukan dalam hal sarana dan prasarana adalah kekurangan ruang kelas, kekurangan ruang terbuka dan media terapi.

1. Solusi kekurangan ruang kelas.

a. Solusi kekurangan ruang kelas

b. Jenis luaran yang dihasilkan

2. Ruang terbuka

a. Solusi ruang terbuka

b. Jenis luaran yang dihasilkan

3. Media Terapi 
Media terapi merupakan salah satu paling utama dalam proses pembelajaran dengan jenis terapi yang ada. jenis terapi begitu banyak untuk penanganan anak autis, maka media atau alat terapi tentu menyesuaikan dengan jenis terapi. Media dan alat terpai masih banyak kelemahan dan masih banyak kekurangan serta media terapi belum menyentuh unsur teknologi.

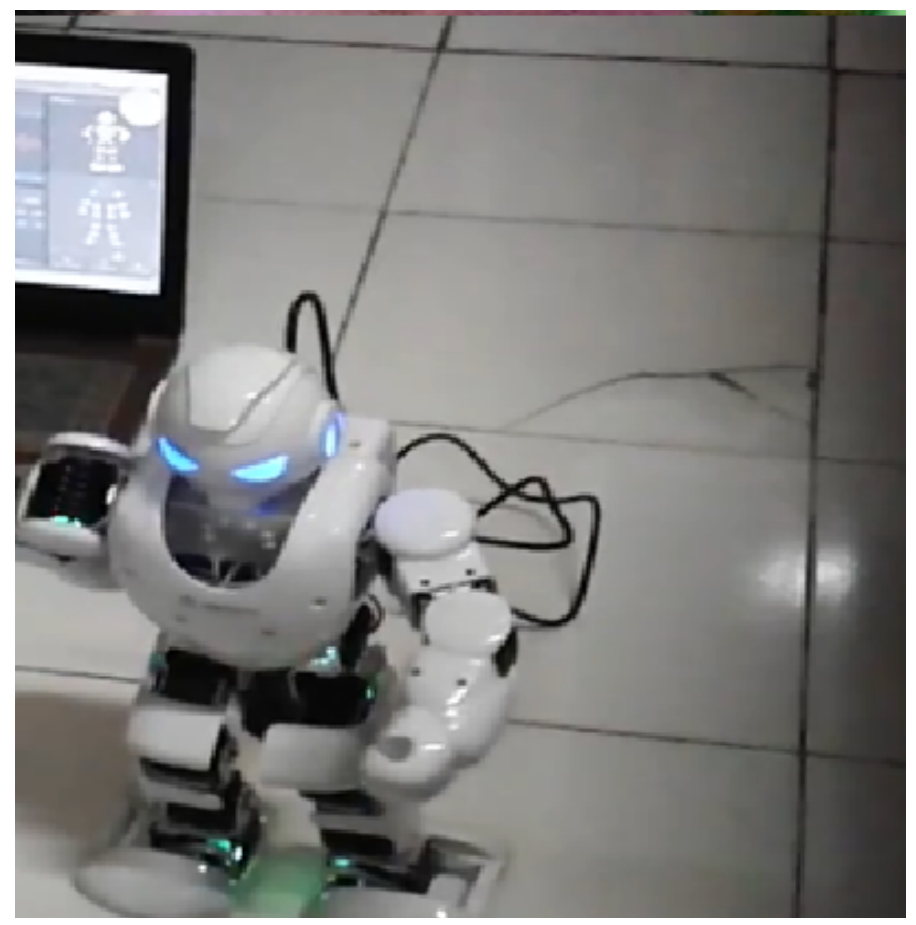

Gambar 5 Tampilan Robot Humanoid

\section{Solusi untuk media terapi}

untuk solusi media terapi perlu adanya pengadaan media terapi yang baru sesuai dengan perkembangan zaman dan hasil riset dari penelitipeneliti.

2. Jenis luaran yang dihasilkan

\section{Solusi dan Luaran Aspek Metode Pembelajaran}

Metode pembelajaran merupakan faktor penting dalam layanan pendidikan kepada anak autis. Permasalahan-permasalahn yang ditemukan di sekolah Pekanbaru Lab School adalah media terapi, kurikulum dan evaluasi.

1. Solusi dan Luaran Kurikulum

a. Solusi untuk kurikulum

b. Jenis luaran yang dihasilkan.

2. Solusi dan Luaran Evaluasi

a. Solusi untuk Evaluasi

b. Jenis luaran yang dihasilkan 


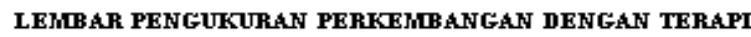
BERMAIN PADA ANAK AUTIS DENGAN MENGGUNAKAN ROBOT HOMANOW

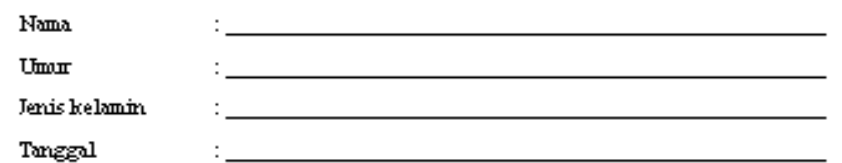

Tanegel

\begin{tabular}{|c|c|c|c|c|}
\hline No & Matei & Fretest & Posttest & Keterangan \\
\hline 1 & Kemammuanmemperthatiban & & & \\
\hline 2 & Kemampuanmeniruban & & & \\
\hline 3 & Kemampuanmengindertilifasi & & & \\
\hline 4 & Kemampum labeling(barna) & & & \\
\hline
\end{tabular}

Rentang Nini $5=$ Tidak Bres $55>100=$ Bages
Grru Fendininging

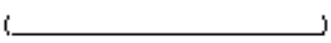

Gambar 6. Model Evaluasi

\section{KESIMPULAN}

Dari pembahasan laporan kemajuan pengabdian kepada masyarakat melalui kemitraan dengan sekolah pekanbaru lab school dapat disimpulkan sebagai berikut :

1. Ubtech Humanoid Robot merupakan salah satu robot yang bisa sebagai media pembelajaran bagi siswa autis dan bisa juga menjadi alternatif guru untuk pembelajaran.

2. Revolusi Industri 4.0 dibidang pendidikan merupakan solusi yang baik untuk Saran mencegah anak terutama anak autis sebagai media interaktif.

Pelaksanaan pengabdian ini ada beberapa hal yang perlu ditindak lanjuti yang bisa di uraikan dalam bentuk saran sebagai berikut :

1. Diperlukannya pengembangan robot yang lebih humanoid dan ramah terhadap manusia terutama anak autis.

2. Diharapkan robot yang akan datang bisa bersifat yang sesuai dengan keinginan masnusia dalam melakukan aktifitas.

3. Diharap guru juga meningkatkan pemahaman terhadap teknologi.

\section{DAFTAR PUSTAKA}


[1].Martins, R., Bonito, I., Andrade, A., Albuquerque, C., \& Chaves, C. (2015). The Impact Of The Diagnosis Of Autism In Parents Of Children. Procedia - Social And Behavioral Sciences, 171, 121-125. Https://Doi.Org/10.1016/J.Sbspro.2015.01.097

[2].Olvkhg, E., Uhvsrqvi, Y. L. H. Z. X., \& Rgxfwlrq, Q. W. U. (2012). \& Rqvwuxfwlrq Dqg \$ Ssolfdwlrq Ri Wkh lhwzrun \& Odvv Lq\% Ohqglqj. 2, 561564. Https://Doi.Org/10.1016/J.Ieri.2012.06.134

[3]. Schwaibold, H., Wiesend, F., \& Bach, C. (2018). The Age Of Robotic Surgery Is Laparoscopy Dead? Arab Journal Of Urology, 16(3), 262-269. Https://Doi.Org/10.1016/J.Aju.2018.07.003 